MICHAŁ IGIELSKI

\title{
Changes in personnel policies of enterprises conditioned by the identification of knowledge workers
}

Michał Igielski, Ph.D. Gdynia Maritime University, Faculty of Entrepreneurship and Quality Science

\section{Introduction}

In the 21st century, in our times operating enterprises more and more appreciate the role of intangible resources, in creating and in achieving the competitive advantage on the global market. Their owners became convinced that possibilities of achieving market successes with the support of "cheap labour" had ended. It can be proved by indicators which dynamically developing companies are reaching in the world, basing their activity on intangible sources, mainly on knowledge and information. It became a fact that the market evaluation of some enterprises, on world stock exchanges, many times exceeded their nominal accounting figures, exactly thanks to intangible stores possessed by them.

Therefore, managing contemporary enterprises faces many challenges, which the knowledge-based economy is creating. The changing reality has forced the transformation of traditional enterprises into the ones which are relying on the knowledge, competence and abilities of their employees. And so management methods are changing, since wanting to exploit knowledge, 
organizations must improve crucial competence, by developing the abilities of employees.

Thus, people are becoming basic strategic resources - with endless source of creating new values and building the competitive advantage. Their development in the enterprise is perceived as the process of systematic improving, accumulating and the knowledge exploitation using effective tools, including incentive.

Therefore, so that enterprises are able to compete on the market, they must take action aiming at the identification and effectiveness in managing knowledge workers, who more and more often emerging as their crucial capital. The effective use of the potential, which is lying in this group of employees, through personnel policy adapted for their expectations, should be a challenge for companies at present, because regards intangible, often difficult to measure elements.

The above mentioned changes in perceiving the intellectual capital also extort changes in the management, the role of which at present becomes getting all most valuable features out of every member of the enterprise. It will become even more effective if employees aspire to constant improving, in which the role of employer is brought to providing for them the best possible conditions for the development. It means that in the contemporary management we can observe the tendency of changes in perceiving the intellectual capital in enterprises, eventually through the prism of individual attributes of each of employees. It is the result of many factors which determine the intellectual capital of individual persons, which mainly include: educational process; acquired experience; acting in different situations; reactions in determined situation in lives. The optimal involvement of human capital in the enterprise, which consciously is using the knowledge for the development of its competitive position on the market, depends, among others, on decisionmaking persons, on the management system accepted by them, influencing the effectiveness and performance of the work. According to the author of the article, the application connected with the development of the intellectual capital, its identification and measurement form the knowledge triangle of the intellectual capital management, which every enterprise needs to remember wanting on these foundations to build its competitive position on the market (Igielski 2014, p. 133).

Therefore, the purpose of this the article is the attempt to indicate, on the basis of an analysis of literature and empirical examinations, the latest trends of the personnel policy in enterprises, which identified knowledge workers 
and are directed at the optimal use of their potential for implementation of the established company's goals.

\section{New trends in management}

The European economy within several dozen last years underwent significant transformations, becoming a fully market economy. What is more, at present, it incessantly must face permanent turbulences of surroundings, which are undoubtedly based on globalization processes. Constant changes occurring in it, are leading to the transformations of profiles of enterprises, which must more and more often seek new ways to improve their competitiveness. Also expectations are changing towards the man in the enterprise, a role of the employee is changing, and his knowledge, abilities and qualifications are supposed to be a guarantee of the continuity of functioning of the company on the market.

In the traditional approach towards the enterprise management, its attributes were described in the following manner:

- location - physical, e.g. a production unit, magazines, offices,

- final products - tangible products, e.g. cars, computers, planes,

- means of production and raw materials - raw materials, semi-finished products, energy, financial capital,

- ways of acquiring resources - operations on the financial market, mergers, takeovers,

- market - local market (global market available only to large enterprises).

Presently, such a description does not seem to be a reasonable approach, as any changes of the environment, more and more frequent and unusual so far, treat the management as a constant and permanent process, which consists of mutually linked and sequentially arranged, previously planned, actions. This approach provides an opportunity to achieve a state of constant flexibility in adapting to the changing business environment.

It is transferred also into the strategic management, whose goals must take into account all stakeholders of the company, who even in the least degree affect its functioning. To manage to carry it out, a specific and consistent action plan is necessary, which will use all available competence of employees of the enterprise.

The personnel function over several years has undergone a large evolution. This was influenced, among others, by changes in the economy and business environment. Significant changes have occurred as a result of the impact of the knowledge-based economy on businesses, where the dominant values 
become knowledge, information, specialization. Intellectual capital, especially human capital in an economy based on knowledge gained great significance. A determinant of development becomes a man who has the resources of knowledge, creates innovation. It is capable of creativity and entrepreneurship, focused on the development and expansion of knowledge, which is used for the development of the organization in which he works. Changes in the economy and in relation to man (to demands on him and his capabilities) caused changes in the HR function and the creation of new management trends such as learning organization, career "without borders", international management, talent management. These changes resulted in the founding concepts of human resources have become inadequate and there was a need for continuous development of the HR function. The impact of conditions for the functioning of the economy based on knowledge and the emergence of new trends, affects the change of the direction of the HR function into human capital (Huk 2013, p. 34).

The attention here is drawn by the fact that in the post-industrial era the role of intangible assets has increased and corporate success is perceived in intellectual assets, in particular in (Skrzypek 2002, p. 681):

- the basic knowledge and skills of people achieved in education and employment - it is important, but insufficient to achieve a success factor,

- advanced skills that indicate the possibility of transforming basic knowledge into effective action and the ability to solve real problems of the organization these skills increase the real value of the organization,

- system thinking, which means knowledge about networks, the consequences of decisions and understanding the processes that take place in the environment - it allows to look ahead to the future and anticipating certain interactions and consequences associated with current decisions,

- intrinsic activity and motivation, which include crop of action, motivation and ability to relate success - a well-motivated and creative group of employees cannot only affect the organization's performance, but also help to improve the relations and the ability to accept change.

Summing up the above considerations, it can be seen that companies definitely changed up to now existing management paradigms and increasingly perceive their success in the development of intellectual assets, with a particular emphasis on human capital. It is an extremely difficult and yet critical task, because the capital is an unusual mix of acquired characteristics, including human psychophysical, educated skills during education and presented the attitudes both towards work and private life. 


\section{The essence of personnel policy in enterprises}

Changes in economic life, which necessitated changes in the organization and management of enterprises have also- affected the transformation of the HR function - it is responsible for managing personnel who have knowledge, skills and competence. That changed dramatically the perception of the employee. In today's economy, we look at it through the prism of value produced for the company, among which the biggest role to play has just knowledge.

As already mentioned, the market success of the company is determined by the unique configuration of its resources, tangible and intangible, and the agent, both-causative and implementing the necessary actions in this regard, are the internal customers of the organization - its employees and managers. Therefore, a strategic competitive asset of the company, enabling victory in the competitive struggle and seizing a good position on the market are human resources - enabling the organization to acquire knowledge and to establish organizational practices and flexible response to changing circumstances. In this context, with the development and launch of a strategic management, the concept of strategic management of social potential was developed. Strategic human resources management is now recognized as the most important factor enabling the company to meet the dynamically changing economic conditions in the environment, and adapting to attitude changes and expectations of employees. Strategic personnel management involves decisions that relate to staff. They direct the activities in the sphere of personnel in a long-term and are essential for achieving the objectives of the company. In addition, they support the company's operations, which are focused on getting its competitive advantage. In a strategic approach to personnel management the emphasis is put on (Maniak 2003, p. 131):

1. Treating employees as assets (core capital) of the company.

2. Taking into account the influence of the environment, and in particular competition and labour market.

3. Activity in the long term.

4. Linking with the overall strategy of the company as well as its structure and organizational culture (values).

5. Consideration of the entire population of employees, not just managers.

6. Change and development, as essential conceptual categories and phenomena.

Developing a consistent and coherent, but also flexible personnel policy is the only guarantee of effective use by the company potentials that lie in their 
employees. All actions must be focused on employee development, which should bring out their creativity and energy, and contribute to the full commitment of the goals set. The fundamental role of the modern HR strategy is to identify due to which competences and with what skills the company will gain a strong and sustainable competitive position.

Formulating the strategy and personnel policy must become an integral part of the formulation of overall corporate strategy. It is proposed that the basic techniques and activities related to human resources (including areas such as recruitment and selection, work-management, payroll management, training and development) are referred to the economic strategy of the company at the following three levels (McKenna, Beech 1997, pp. 31-32):

1. Strategic level, where the focus is on the common area between the company and the environment - a priority sphere of interest is the enterprise as a whole. In the area of HRM at this level must be specified:

- successive planning - the desire to provide the organization with the next generation of managers,

- human resource planning - long-term forecasting of the volume and structure of demand for labour,

- management tasks - defining the type of work and evaluation systems, stimulating to achieve the best results,

- management salaries - deciding on the most effective system and identify the types of remuneration that should be linked to achieving long-term economic objectives,

- training and development - creating a general plan of development of the organization in order to inspire future employees.

2. Control level (tactical) - meaning the improvement of policies, practices and systems for social potential of the organization. The policies and strategic plans for the areas of HRM are translated into concrete systems, e.g. recruitment and selection, salaries and employee motivation.

3. Operational level - very important in the concept of HRM- uses tools developed by the tactical level to the current human resource management organization. The above process is a kind of transition to activities typically staffing, to treat the personnel function in a strategic way for the organization.

A strategic approach to human resource management can be defined as a set of long-term measures for the preparation and implementation of HR strategy, which supports the aspiration of the organization to achieve its competitive advantage. As the essential features of a strategic approach to human resource management include: the perception of people as assets and basic capital of the 
company; environmental influences - mainly on competition and the labour market on personnel decisions; personnel decisions with extended time horizon related to the overall strategy of the company, its structure, organizational culture and values; activities of a proactive rather than reactive nature; taking into account the entire population of employees, not just managers (Tyrańska 2009, p. 355).

Accordingly, a strategic approach to HR policy must focus on two planes. First and most importantly, according to the author of this study, the employees should be viewed not as a cost, or even a resource, but as capital in their organization. Secondly, the company's strategy should be linked to the tasks arising from its personal function.

\section{Identification of knowledge workers in enterprises}

In the last decade we saw rapid development of new forms of organization associated with different phases of social development. There has been a shift in focus from financial capital (tangible) to capital of knowledge and social development, as generators of above-average revenue of the company. The primary function of management has become making knowledge productive. This is accompanied by changes in human resource management. A dominating employee in terms of value creation is the knowledge worker (Grudzewski, Hejduk 2011, p. 95).

The term knowledge worker, was first used in the 60s by P.F. Drucker. Since that time, there has occurred many interesting definitions of this group of people that emphasize the importance of education, their characteristics or participation in certain activities. Below, the author of the studies presented in a synthetic manner the existing definitions of knowledge workers, bearing in mind the objectives of this article:

1. P.F. Drucker (1997, p. 21) - knowledge workers apply theoretical and analytical knowledge acquired through formal education, the development of new products or services.

2. E. Skrzypek (2002, p. 683) - knowledge workers have professional skills, interpersonal skills and unique skills, the use of which creates added value.

3. T.H. Davenport $(2005$, pp. 10, 22) - the main purposes of their operation include creation, dissemination and practical application of knowledge.

4. M. Morawski (2003, p. 19) - knowledge workers are trained in their profession, they have unique skills and are aware of their role and self-esteem as independent participants of the organization.

41

MICHAt IGIELSKI 
In contrast, W. M. Grudzewski and I. K. Hejduk (2011, p. 116) split the group into five categories:

- producers of knowledge: scientists, engineers, but also lawyers, judges, architects, consultants, accountants,

- distributors of knowledge: teachers, librarians, editors, writers, authors and radio and television presenters,

- market researchers and coordination specialists: brokers, retailers, sales representatives, some members of the administration,

- information workers: secretaries, accounting clerks, editors, employees working on telecommunication or electronic machines.

In turn, L. A. Berger and D. Berger (2004), based on the research, pointed to key skills of knowledge workers, along with their corresponding attributes used at work. They passed to them:

1. Orientation to activity: setting and achieving goals, overcoming obstacles, defining standards of performance, taking responsibility, operation efficiency and activity.

2. Communication - effective communication of information, sharing of ideas, listening carefully, identifying the key content in the messages.

3. Creativity and innovation - creating new ideas, developing ready solutions, encouraging others to think.

4. Critical thinking - defining obscure issues, focusing on emerging problems.

5. Orientation to clients - listening carefully to customers, building loyalty relationships with customers, increasing their satisfaction, commitment to their problems, recognizing their expectations and responding to them.

6. Interpersonal skills - effective networking conversations with others, showing trust in relations with others.

7. Leadership - motivating, inspiring, collaborating, encouraging, conflict resolution.

8. Teamwork - building effective teams, creating favourable conditions for work.

9. Technical expertise - demonstrating high level of technical professionalism and expertise, having full knowledge of the company.

To make the knowledge worker effective, they must have new powers that are oriented towards creativity and the ability to construct new products, services and ideas. It is listed nearly 30 new competencies, of which the most important are: orientation to action, communication, creativity, critical thinking, customer orientation, interpersonal skills, leadership, teamwork, technical expertise. The characteristics of knowledge workers and the subject of their work make conventional management systems do not fulfil their task. While today, thanks 
to Taylor, the father of scientific management, we know a lot about raising labour productivity workers, whereas raising the productivity of knowledge workers is a challenge. Key questions related to the knowledge worker within a few decades will result in significant changes in the structure and nature of the economic system. It is in this area a place for promising new concepts of governance that will reflect not only the nature of the work, but also features of the generation. It is expected that they will develop social norms based on the principles, standards, personal responsibility. Different areas of life will be more structured and oriented to civil society. Their relationship with the employer often will have a long time horizon (Grudzewski, Hejduk 2011, p. 98).

To effectively engage knowledge workers in creating a competitive advantage in the market, accurate information about the effects of their work is necessary. However, this is one of the major problems in this area, because unlike the traditional routine forms of work that do not require the above specified powers together with attributes, knowledge-based work is not usually difficult to measure. This is mainly due to its qualitative nature, which often lacks appropriate indicators. Besides, in this process time plays an important role as well - the effects of an action taken by a knowledge employee can be practically seen after a long stretch of time. It is difficult to judge whether to compare the work for example: of two architects, taking as a criterion for their assessment the number of prepared projects per month. This problem became much visible when doing research, especially in Polish enterprises, where still the main criteria for evaluation of the employees are measured using quantitative indicators. This is also translated into motivational problems that arise often unsuited to the key personnel strategies for the enterprise of modern workforce (knowledge workers) - their needs are often much more complex and less standard than other employees'.

\section{Towards personnel strategies tailored to the needs of knowledge workers}

Managing knowledge workers is extremely difficult and what is worst, will be even more difficult. This is due to the fact that their superiors do not have actual power over them - they have a problem with influencing them and controlling. In changing conditions, in new models for businesses, they cannot command them, just need to work together. Therefore, there changes the role of not only employees but also employers who need to be organizers of the optimum operating conditions, allowing free use of the knowledge by their employees. 
Below the author of the article tried to show the changes that occur in the last period in enterprises operating in the market economy:

1. Perception of the employee:

- career-oriented (before) - work and life balance (currently),

- stable - mobile,

- subject to permanent control - trust,

- lifetime with one employer / stability - several years with one employer / collaboration time,

- hierarchically placed in the company - working in project teams.

2. Perception of the employer:

- office / fixed working hours (earlier) - virtual contact / teleworking (now),

- the main goal is profit - goal is to increase competitiveness and goodwill in the market.

- attitude to the routine - focus on innovation.

3. Perception of HR strategy:

- restructuring (before) - knowledge and expertise management (currently),

- hierarchical organization - an organization flattened / flexible,

- functional workplace - self-tracking teams,

- hard skills - competence,

- wages - the total remuneration,

- HR function - strategic function.

These tendencies to change are confirmed in business practice that became apparent during empirical research conducted by the author of the article.

The study, conducted in late 2013 and 2014, included 100 major companies operating in the Baltic Sea Region - was carried out as part of the research conducted by the author-of the article. The main objective of the research was to determine the effect of knowledge workers on the competitive position of the company. In turn, the specific objectives related to:

- determine the conditions and criteria for determining the affiliation of the worker to the concerned group of knowledge workers,

- identification of knowledge workers in enterprises that participated in the study,

- identification of barriers faced at work by knowledge workers,

- determination of activities (changes in the personnel policy of enterprises) to help in the effective work of knowledge workers,

- identify desirable attitudes of managers by their staff.

The research included two areas: the analysis of internal documents of companies and three groups of employees of these companies - middle managers 
and senior managers (decision makers), their subordinates and indicated (by the human resources departments in the surveyed enterprises, through analysis and consultation) persons having the greatest impact on the company. For the purposes of this study, which represents only a small part of the whole research, the analysis will focus on only two groups of respondents: A total of 328 workers - 250 people in managerial positions and 78 selected as important for the company, who completed two separate survey questionnaires, which include the following types questions:

- closed alternative,

- closed filtering,

- closed that use nominal and ordinal scale

- determining the rank of importance of the analysed topics,

- semi-open as a conjunction,

- controlling that allows to check the sincerity of the respondent,

- test "Self-Portrait of Stein" - is used to identify the needs of respondents and survey the level of expectations,

- questions to identify social factors - used to determine issues related to communicating or role in the whole process of management.

At the beginning it is worth noting that the company did not use the concept of the knowledge worker. This greatly hindered the research process, because it was necessary to try to identify these people, which in Polish conditions turned out to be the most difficult. However, after establishing the criteria and conditions affecting the affiliation of the worker concerned to the group of knowledge workers, it can be assumed that in 38 companies (representing 38\% of the study group) it was possible to identify to such persons in number 41 , which is less than $13 \%$ of all respondents -a detailed picture is shown in figure 1. It is also worth noting that further presented results will only affect this group of companies and their workers.

The starting point for further considerations is to show the role the identified knowledge workers play and their impact on the functioning of enterprises in the market. After a number of analyses of empirical material and existing data, we managed to extract individual aspects of business operations in a market whose shape is greatly affected by this group of workers. Below the author of the article presented a broader description of the identified areas, and figure 2 shows the percentage system relating to the companies participating in the research:

1. The ability to identify emerging markets, market niches, customers' needs - to find market niches and gaps in the needs of customers. 


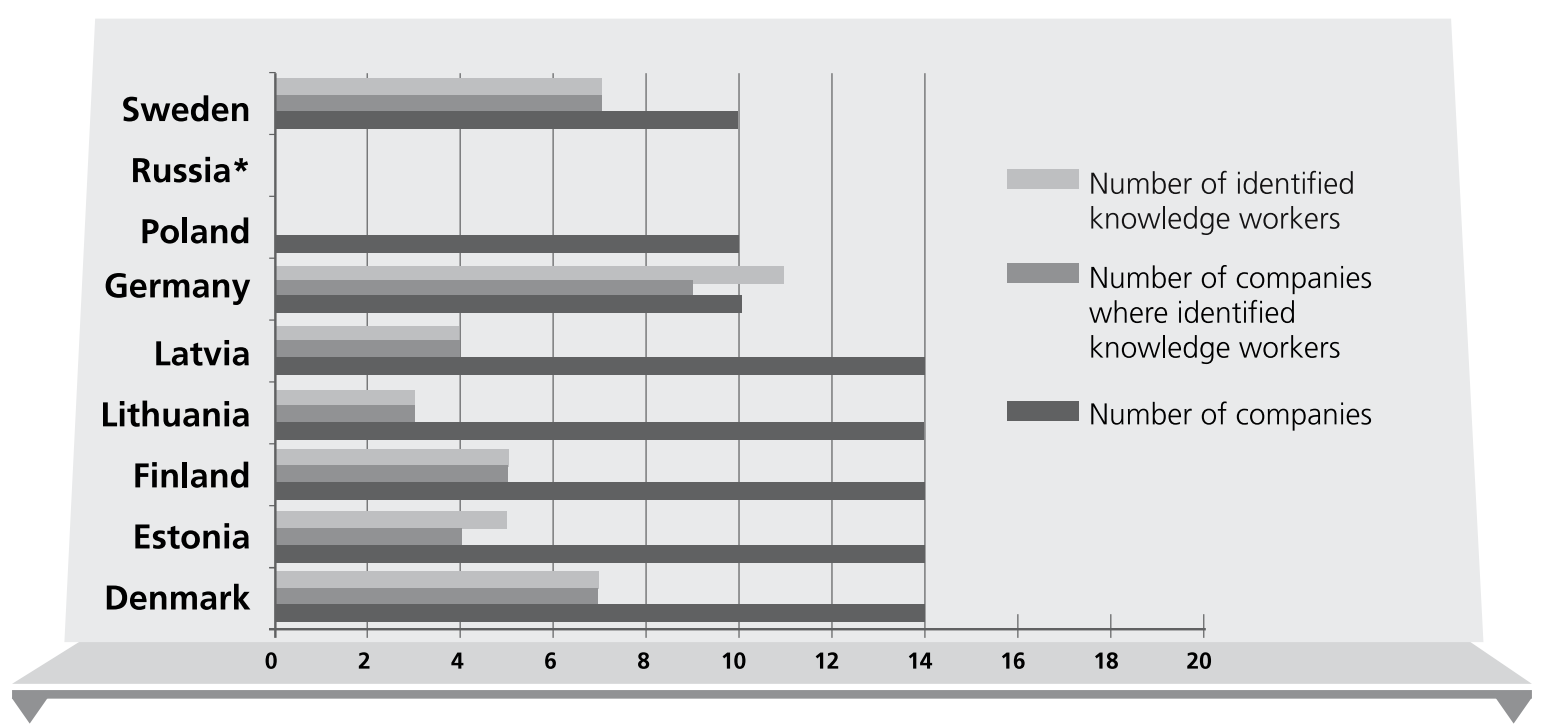

Figure 1. Registered knowledge workers in the surveyed enterprises (* Russia due to the prevailing political situation did not take part in the study)

Source: own study

2. The ability to produce products providing a competitive advantage - finding the unique characteristics of the products or services.

3. The ability to acquire materials and components and use them as a source of product development - the ability to combine in a unique semi-final product.

4. Proficiency in conducting manufacturing and marketing processes streamlining business operations.

5. The ability to innovate and improve service - as above.

6. Contacts with clients - building long-term relationships.

7. Creating alliances with technology leaders - working with the best partners.

8. Relationship with suppliers - to build competitive advantage on the basis of cooperation with suppliers.

9. The ability to use new technological knowledge in the organization through training and education - the search for new paths to self-development of the company.

In summary, the above data clearly indicates the significant share of knowledge workers in building a competitive position of their businesses in the market. It is also impossible to deny the thesis that without their contribution, to the implementation of the company's strategic goals would not have been eventually possible. 


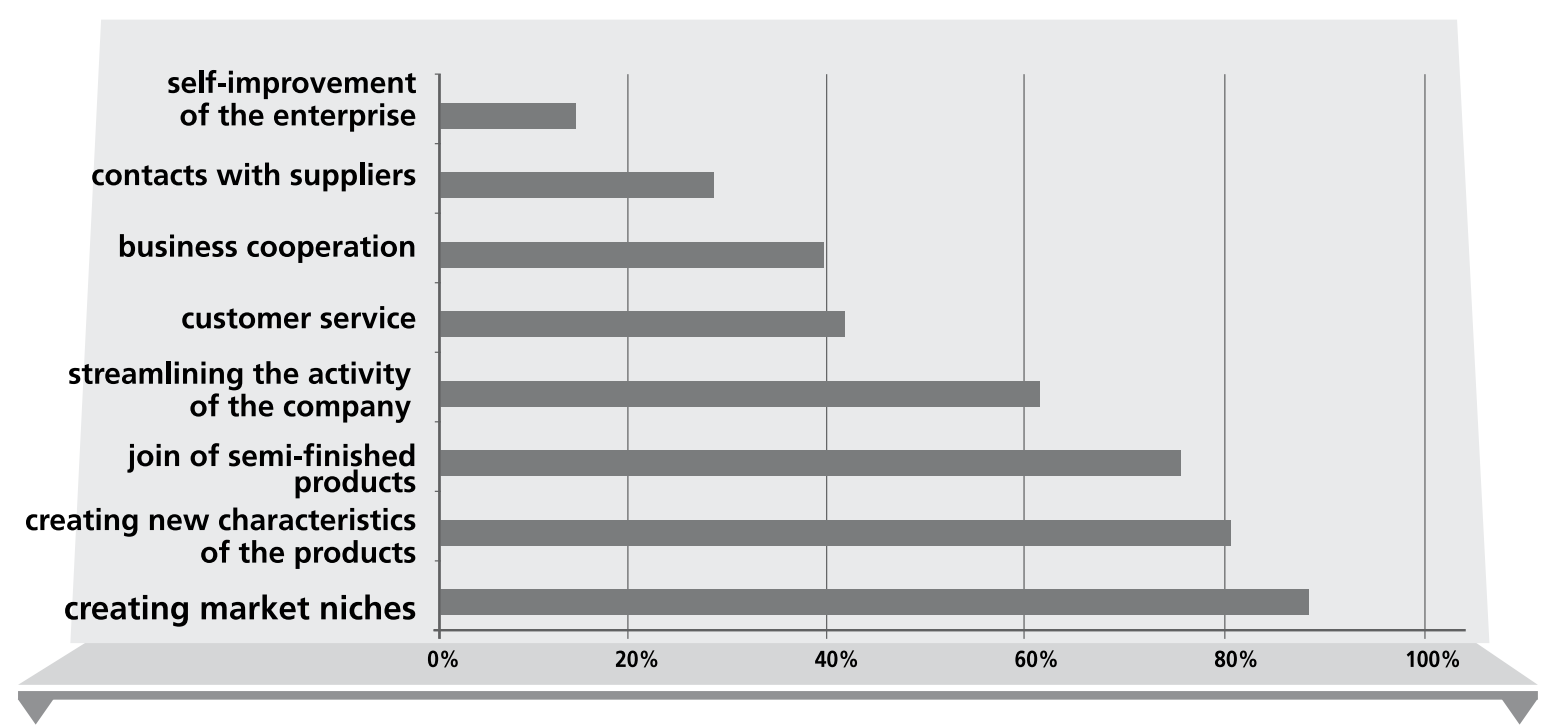

Figure 2. Areas of greatest impact of knowledge workers in enterprises involved in the stud

Source: own study

But to talk about the effective use of knowledge workers' skills, the surveyed companies, through changes in their personnel policies, had to overcome the barriers standing in the way of this process - the directions of these changes are shown below, and existing barriers to this process are determined in figure 3:

- due selection of team members, of managers, based on concrete rules of the recruitment,

- additional trainings for all employees,

- determining the appropriate involvement, i.e. roles and respective spheres of competence,

- supporting employees by the dense management board of business data,

- implementing universal standards and tools of the management.

Striving central management to make changes in listed above directions, consciously using the knowledge to develop, led the surveyed enterprises to change the management system, affecting the efficiency and productivity by:

- regulation of conditions and working hours,

- creating a system of remuneration interacting with incentive schemes,

- caring for a positive atmosphere at work,

- providing a sense of job satisfaction,

- ensuring a sense of job stability, 


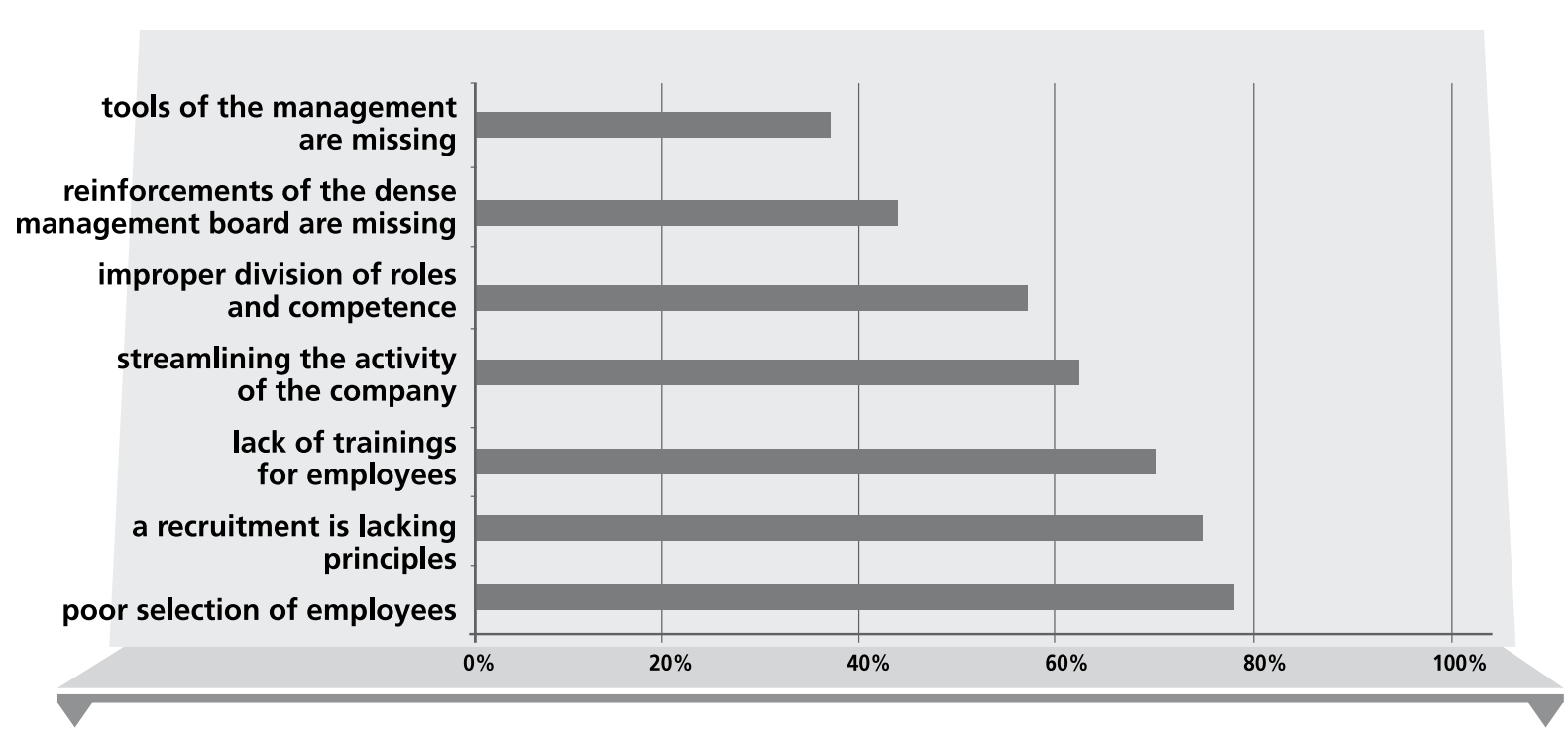

Figure 3. Barriers to the personnel policy of enterprises participating in the research that prevent optimal use of knowledge workers

Source: own study

- appropriate division of opinions among employees,

- changing the system of checks into the system of support and coordination,

- creating innovation.

To sum up, regardless of which method or strategy-a company chooses to support (and even build) your business goals through optimal management of knowledge workers must resist this sphere of activity on specific rules:

1. All employees in the company must be treated as capital.

2. Organizational culture is the basis for human capital management.

3. The creation of a specific (flexible) business model that interacts with the strategy of personnel.

4. The breakdown of responsibility for human resources management at several centres in the company.

5. The objectives of the employer synonymous with the goals of employees cooperation and full commitment to the job.

6. Raising awareness about the role of senior management competencies of employees in their company - they must trust them and properly motivated.

7. The competent definition of tasks for the HR Department - primarily to help solve social problems in the company. 


\section{Conclusions}

Unfortunately, in the economic market there are still barriers that impede optimal utilization of the potential of employees to the company's development. These include e.g. bad recruitment, lack of mechanisms and management standards, poor motivation or avoiding investment in employee development. It is worth mentioning that during the study there were not identified knowledge workers in any of Polish companies and what is even worse, actions aimed at building a competitive advantage based on the competencies of employees were the smallest.

It should be also borne in mind, however, that the area to identify and exploit the potential of knowledge workers is a relatively new practice, besides the United States of America where this concept has existed for around 50 years.

Knowledge workers are the new, ever-growing group of employees that differs not only from traditional / routine employees but also white-collar workers with high intellectual potential. This difference may not be very clear, but causes big problems during their identification. But surely it can be stated that it is hard to find, in the contemporary market situation, other alternatives for the development of the organization. Everyone must understand that there is no possibility of building a competitive advantage through continuous investment in tangible resources and preparing internally to co-operate with that same group of people. According to the author of the article, it is the only antidote to changes in the external environment of the organization and only they will be able to lead it through such a turbulent environment for success. But to do that it is necessary to implement changes in strategic management, together with the adjustment of personnel strategy to the needs of knowledge workers, which will be a great challenge for management and HR departments today.

\section{Abstract}

\section{Changes in personnel policies of enterprises conditioned by the identification of knowledge workers}

The twenty-first century requires enterprises to change in their functioning, since management has been faced with an unprecedented challenge so far - it is the result of a turbulent external environment. Due to transformations the companies cannot continue to build their competitive advantages based on investments in tangible resources and cheap labour. They have to turn into organizations based on knowledge, skills and 
competencies, which involves the use of new management methods. Therefore, the most desirable employees are those who through education, skills and experience are able to help businesses operate on the market. Companies in their strategies appreciate knowledge workers, who in the world today, in the era of endless crisis, can decide and determine gaining a competitive position in the market. We must also remember that the policy of qualification and skills of knowledge workers must arise from the strategy of personnel of the company. Therefore, the author of this article believes that it is necessary to customize personnel strategies in enterprises to the needs of knowledge employees working in them.

Keywords: personnel policy, knowledge worker, competitiveness, enterprise

\section{Streszczenie}

Zmiany $w$ politykach personalnych przedsiębiorstw uwarunkowane identyfikacją pracowników wiedzy

XXI wiek wymusza na przedsiębiorstwach zmiany $w$ ich funkcjonowaniu, gdyż zarządzanie nimi staje przed do tej pory niespotykanymi wyzwaniami, wynikającymi $\mathrm{z}$ turbulencji otoczenia zewnętrznego. Przemiany rynkowe spowodowały, iż przedsiębiorstwa nie mogą dalej budować swojej przewagi konkurencyjnej $\mathrm{w}$ oparciu o inwestycje $\mathrm{w}$ zasoby materialne i tanią siłę roboczą. Muszą przekształcić się $\mathrm{w}$ organizacje bazujące na wiedzy umiejętnościach i kompetencjach, co wiąże się $\mathrm{z}$ zastosowaniem nowych metod zarządzania. W związku z tym najbardziej pożądanymi pracownikami stają się tacy, którzy dzięki wykształceniu, umiejętnościom i doświadczeniu są w stanie pomóc przedsiębiorstwom funkcjonować na rynku. Przedsiębiorstwa w swej strategii działań stawiają właśnie na pracowników wiedzy, którzy we współczesnym świecie, w dobie nie kończącego się kryzysu, mogą i stanowią o zdobywaniu pozycji konkurencyjnej na rynku. Należy przy tym pamiętać, że polityka podnoszenia kwalifikacji i umiejętności pracowników wiedzy musi wynikać z przyjętej strategii personalnej przedsiębiorstwa. Dlatego też autor niniejszego artykułu uważa, że konieczne jest dostosowywanie strategii personalnych $w$ przedsiębiorstwach do potrzeb pracujących w nich pracowników wiedzy. 


\section{Słowa}

kluczowe: polityka personalna, pracownik wiedzy, konkurencyjność, przedsiębiorstwo

\section{References}

1. Berger L.A., Berger D.R. (2004), The talent management handbook: creating organizational excellence by identifying, developing and promoting your best people, New York, The McGraw-Hill Press.

2. Davenport T.H. (2005), Thinking for a Living. How to get better performance and results from knowledge workers, Boston-Massachusetts, Harvard Business School Press.

3. Drucker P.F. (1997), Management challenges for the 21st century, New York, Truman Talley Books Press.

4. Grudzewski W.M., Hejduk I.K. (2011), Changes of paradigms of the management, Master of Business Administration.

5. Huk K. (2013), Growth in importance of the man in the economy based on the knowledge - from the personnel management for administering the human capital, Social inequalities but the growth in the economy.

6. Igielski M. (2014), Of challenging the human capital management in enterprises in economy conditions based on the knowledge, in. M. Blaskova, E. Matuska (ed.), Human Potential Development, Higher Hanseatic School of Management in Slupsk Press.

7. Maniak G. (2003), Strategia personalna firmy - strategia funkcjonalna czy uwarunkowanie strategii rozwoju, Scientific booklets of the Szczecin University, Uniwersytet Szczeciński Press.

8. McKenna E., Beech N. (1997), Human resources management, Warszawa, Gebethner\&Ska Press.

9. Morawski M. (2009), Managing professionals, Warszawa, Polskie Wydawnictwo Ekonomiczne.

10. Skrzypek E. (2002), Place of managing information and the knowledge in the corporate strategy, in. A. Stabryła (ed.), Manage a company in the information society, Kraków, EJB Press.

11. Tyrańska M. (2009), Personal strategies in contemporary enterprises, in L. Kozioł (ed.), Scientific booklets of Małopolska Wyższa Szkoła Ekonomiczna w Tarnowie, Małopolska Wyższa Szkoła Ekonomiczna w Tarnowie Pres. 